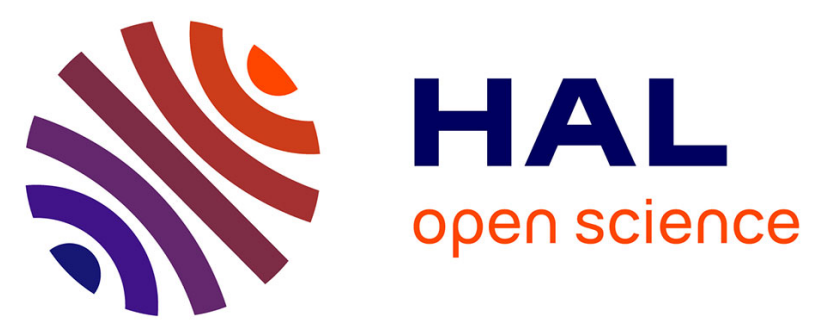

\title{
Characterization of a composite structure obtained by RFI using HexFIT® semi-products
}

\author{
Philippe Marguerès, Jean-Noël Périé, Julian Gutierrez Perez, Francis
}

Collombet, Yves-Henri Grunevald

\section{To cite this version:}

Philippe Marguerès, Jean-Noël Périé, Julian Gutierrez Perez, Francis Collombet, Yves-Henri Grunevald. Characterization of a composite structure obtained by RFI using HexFIT® semi-products. Composites Science and Technology, 2009, 69 (1), pp.117. 10.1016/j.compscitech.2007.10.059 . hal00563498

\section{HAL Id: hal-00563498 https://hal.science/hal-00563498}

Submitted on 6 Feb 2011

HAL is a multi-disciplinary open access archive for the deposit and dissemination of scientific research documents, whether they are published or not. The documents may come from teaching and research institutions in France or abroad, or from public or private research centers.
L'archive ouverte pluridisciplinaire HAL, est destinée au dépôt et à la diffusion de documents scientifiques de niveau recherche, publiés ou non, émanant des établissements d'enseignement et de recherche français ou étrangers, des laboratoires publics ou privés. 


\section{Accepted Manuscript}

Characterisation of a composite structure obtained by rfi using hexfit ${ }^{\circledR}$ semi $^{-1}$ products

Philippe Marguerès, Jean-Noël Périé, Julian Gutierrez Perez, Francis

Collombet, Yves-Henri Grunevald

PII:

S0266-3538(07)00433-2

DOI:

10.1016/j.compscitech.2007.10.059

Reference:

CSTE 3882

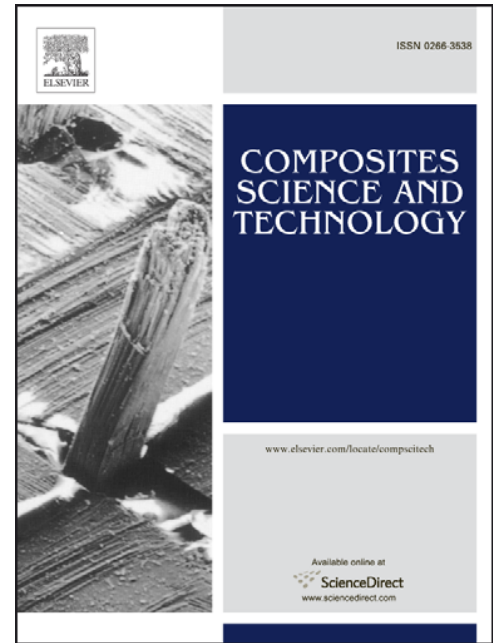

To appear in:

Composites Science and Technology

Received Date:

14 May 2007

Accepted Date:

11 October 2007

Please cite this article as: Marguerès, P., Périé, J-N., Perez, J.G., Collombet, F., Grunevald, Y-H., Characterisation of a composite structure obtained by rfi using hexfit ${ }^{\circledR}$ semi products, Composites Science and Technology (2007), doi: 10.1016/j.compscitech.2007.10.059

This is a PDF file of an unedited manuscript that has been accepted for publication. As a service to our customers we are providing this early version of the manuscript. The manuscript will undergo copyediting, typesetting, and review of the resulting proof before it is published in its final form. Please note that during the production process errors may be discovered which could affect the content, and all legal disclaimers that apply to the journal pertain. 


\title{
CHARACTERISATION OF A COMPOSITE STRUCTURE OBTAINED BY RFI USING HEXFIT $^{\circledR}$ SEMI PRODUCTS
}

\author{
Philippe Marguerès*, Jean-Noël Périé*, Julian Gutierrez Perez*, Francis Collombet* et Yves-Henri \\ Grunevald** \\ *LGMT - PRO²COM - IUT Paul Sabatier - Département GMP - 133, Avenue de Rangueil - 31077 \\ Toulouse cedex 4 \\ **DDL-Consultants - 83330 Le Beausset
}

\begin{abstract}
The HexFIT ${ }^{\mathrm{TM}}$ is a semi-product used for large structures manufactured by the RFI process. In this work, large plate made of a quasi-isotropic lay-up is considered. The presented study aims at mechanically characterizing and identifying the process impact for such a structure. NDT (US \& IR) are first used to highlight material heterogeneities and thickness variations. This approach helps us to define a sampling protocol in order to select tensile coupons taking into account thickness and width. Multi-instrumented tensile tests (strain field measurement, gauges and extensometer) are undertaken on specimens showing different widths but almost same thicknesses. Comparison between the different strain measurements leads to qualify specific sensors for future characterisations.
\end{abstract}

KEYWORDS : RFI, NDT, multi-instrumentation, strain field measurement 


\section{INTRODUCTION}

The work presented herein takes part in a more global study [1] aiming at the characterization and the monitoring of the behaviour of composites structures from manufacture to complete ruin. This is done taking into account the effect of meso- or macro-scale variabilities and the process conditions. A first goal step is to propose a specific experimental protocol leading to define accurate investigation techniques. Here is considered a composite structure made of HexFIT® E-glass/M9.6FL. This semi-preg is dedicated to Resin Film Infusion process and supplied by Hexcel Composites.

\section{RAW MAETRIAL AND MANUFACTURE}

Resin Film Infusion (RFI) is a mix between RTM (Resin Transfer Moulding) and RIM (Resin Infusion Moulding) offering relatively fast and low-cost manufacturing of large composite parts [1, 3]. The HexFIT® semipreg considered in this study is made of preimpregnated $2 \times 2$ twill-weave E-glass fabrics combined with two dry \pm 45 E-glass reinforcements stitched together. The mass per unit area of the reinforcements reaches $1200 \mathrm{~g} / \mathrm{m}^{2}$ (Figure 1). The studied structural part is a $900 \times 900 \times 5 \mathrm{~mm}$ plate manufactured using a vacuum bag oven curing (Figure 2) and following the supplier cure cycle (Figure 3). The used consumable supplies are described in Figure 4. The composite part is a quasi-isotropic and symmetric laminate made from only four plies (Figure 5). It is important to mention here that there's a specific mesoscale structure in the ply due to the different roving sizes used in the reinforcements. On one hand the 2x2 twill-weave fabric shows a 20x20 mm repetitive cell containing large yarns and on the other hand \pm 45 reinforcements containing thinner yarns and stitching (Figure 6).

\section{INITIAL STATE AND INFLUENCE OF PROCESS}

Two cartographies intented to define the initial state of the structural part and realized using ultrasonic echography (Figure 7) and infra-red method (Figure 8). Ultrasonic C-Scan was obtained through 2000 CScan measures performed on the upper face of the plate while it was still on the mould. This non destructive investigation highlights the thickness variation (macroscale) owing to process conditions. In fact, the thickness variation is mostly controlled by the location of the connector to the vacuum pump and the sealant tape and also the flexibility of the vacuum bag for the considered cure cycle:

- $\quad$ thickness near the sealant tape is smaller than the one located near the vacuum sniffer;

- there is a symmetrical variation of the thickness both sides of a line joining the vacuum sniffer location and the median axis of the plate. 
The IR method required more attention because of the dimensions of the plate. In fact misinterpretation on the thickness variation can appear when using the IR measures obtained on the edges of the investigation areas used (numbered from 1 to 48). But ultrasonic or IR information are mainly similar.

An additional inspection using X-Ray technology was undertaken on two calibration test blocks respectively made from four plies of HexFIT® containing only $2 \times 2$ twill-weave E-glass fabrics and four plies of HexFIT® containing only \pm 45 E-glass reinforcements (Figure 9). It confirms the mesoscale effect of the reinforcements (different yarn sizes) but also highlights the macroscale effect of the $2 \times 2$ twll weave E-glass fabrics showing a spacing of about $0.5 \mathrm{~mm}$ between the rovings.

\section{MECHANICAL CHARACTERIZATION}

A sampling was undertaken on the plate in order to obtain standard specimens according to NFT57-101 (Figure 10). This characterization aims at highlighting effect of the variability of the specimens (thickness variation, dimensions) to help at defining future mechanical modelling. First results are given for specimens with similar thickness (same colour code on C-Scan) but different widths according to NFT57-101: 10, 25 and $50 \mathrm{~mm}$ [1]. Figure 11 shows slightly differences in the obtained moduli and the rupture behaviour of the 10-mm-wide specimens.

In order to study the effect of the mesostructure on the global behaviour of such laminates multiinstrumented tensile tests were undertaken using 50-mm-wide specimens. (Figure 12). Three techniques were used:

- $\quad$ longitudinal and transverse strain gauges (Kyowa; $K=2,08 ; 119.6 \pm 0.4 \Omega$ ) bounded on both sides of the specimens; gauges with 10-mm et de 6-mm lengths were compared;

- 80-mm-high-resolution-Zwick extensometer;

Digital Image Correlation (DIC) for full field strain measurements [4].

For DIC measurements, a random white speckle pattern is sprayed onto the initially black painted surface of the samples..Images were grabbed at various loadings and up to rupture with a 14 bit CCD PCO.1600 camera. The analysis performed using the software Correli ${ }^{\mathrm{LMT}}$ focused on local and average strains in order to compare with the other techniques and both strain gauges lengths. 
No significant difference was observed for the different gauges lengths chosen (Figure 13 and Figure 14). However, the effect of the reinforcement clearly appeared on the surface deformation of the tested specimens: periodic patterns appeared during loading. Although strain gauges give local information and can break early, full field strain analysis allows monitoring the local and global information and discriminating the very beginning of the rupture.

\section{CONCLUSION}

This preliminary study allowed us to propose a first experimental protocol to characterize the HexFIT® material used in a large composite plate. US and IR cartographies were used to sample specimens in the for mechanical testing taking into account the thickness variation due to process conditions. Tensile tests undertaken on specimens with different widths and multi-instrumented tensile tests on 50-mm-wide specimens allowed us to highlight limitation in classical tensile tests. Specimens with 10-mm width seam not to be suitable for the characterization of the HexFIT® used in the study. Despite no significant difference between the information obtained through the use of 6- or 10-mm-long gauges and the 80-mm extensometer, the strain full field analysis highlights mesoscale structure influence on the deformation obtained on the inspected surface. A farther comparison between multi-instrumented specimens varying the thickness will be undertaken to complete this first approach. Once done, discrimination of damage mechanisms could be undertaken in function of width and thickness.

\section{BIBLIOGRAPHIE}

1. Lopez Torres J. and Syed Muhammad K. "Characterization of composite material: HexFIT ${ }^{\mathrm{TM}}$, DEA report 2003, University Paul Sabatier III, Toulouse, France.

2. HexFIT ${ }^{\mathrm{TM}}$ "Film infusion Technology for the rapid and cost-effective manufacture of composites" HEXCEL Composites product literature, March 2001.

3. "Resin film infusion composites cost reducer", 2002, REINFORCED plastics - Elsevier Science, Feb., p.44-49.

4. Hild F., Raka B., Baudequin M., Roux S. and Cantelaube F. (2002). "Multiscale displacement field measurements of compressed mineral-wool samples by digital image correlation." Applied Optics 41(32): 6815-6828. 
Figure 1: HexFIT material

dry stitched \pm 45 reinforcements

preimpregnated

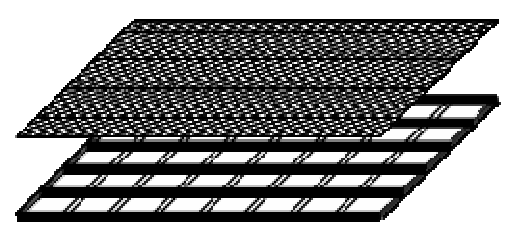

$2 \times 2$ twill-weave fabries

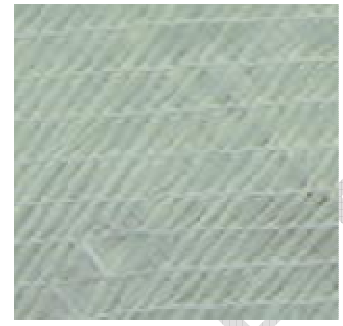


Figure 2: Mould: schematized and in oven

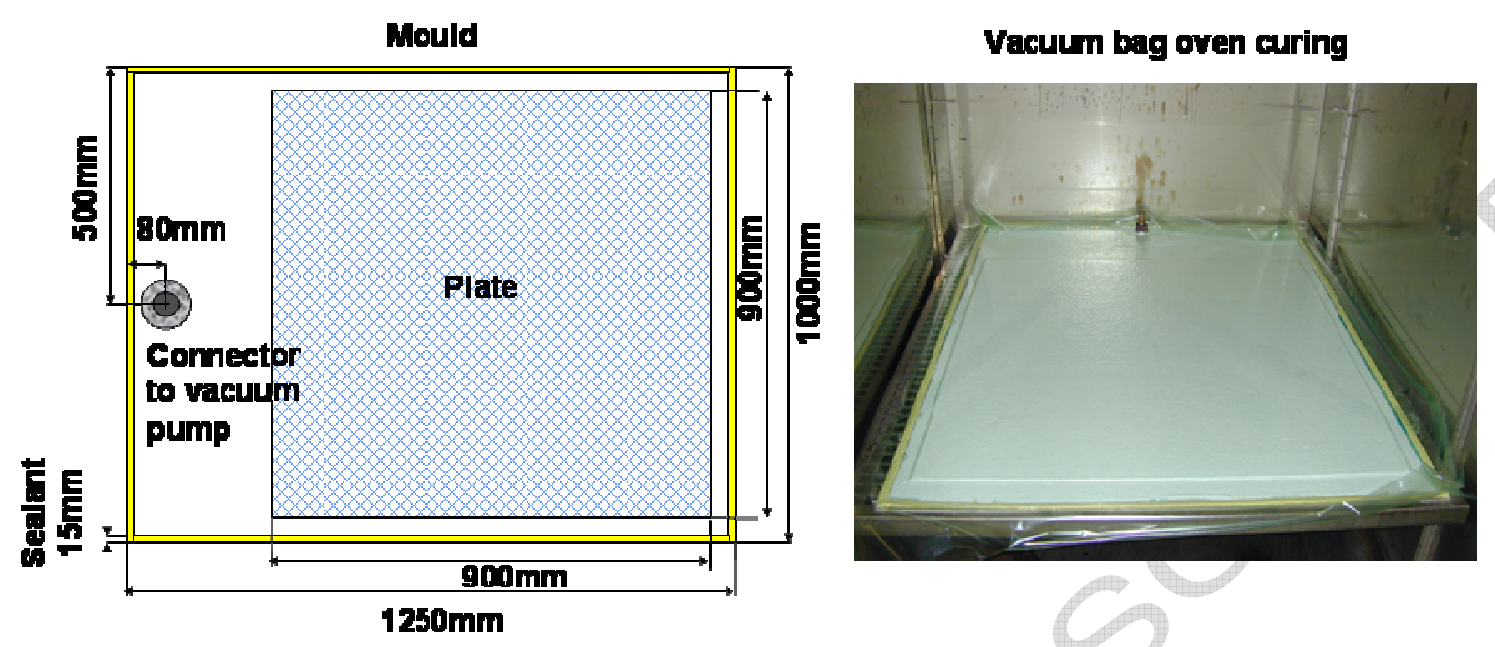


Figure 3: Cure cycle

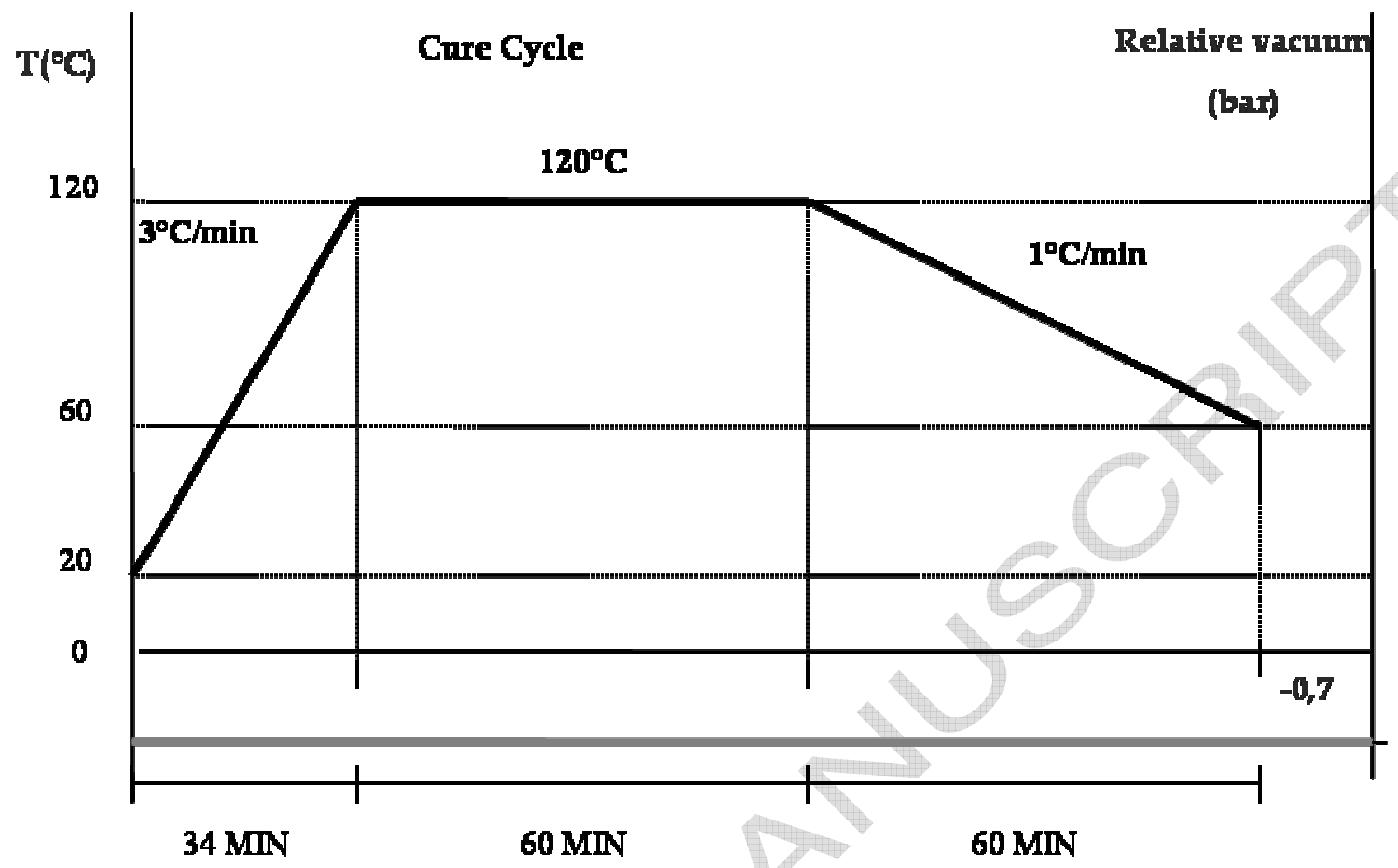


Figure 4: Consumable supplies used

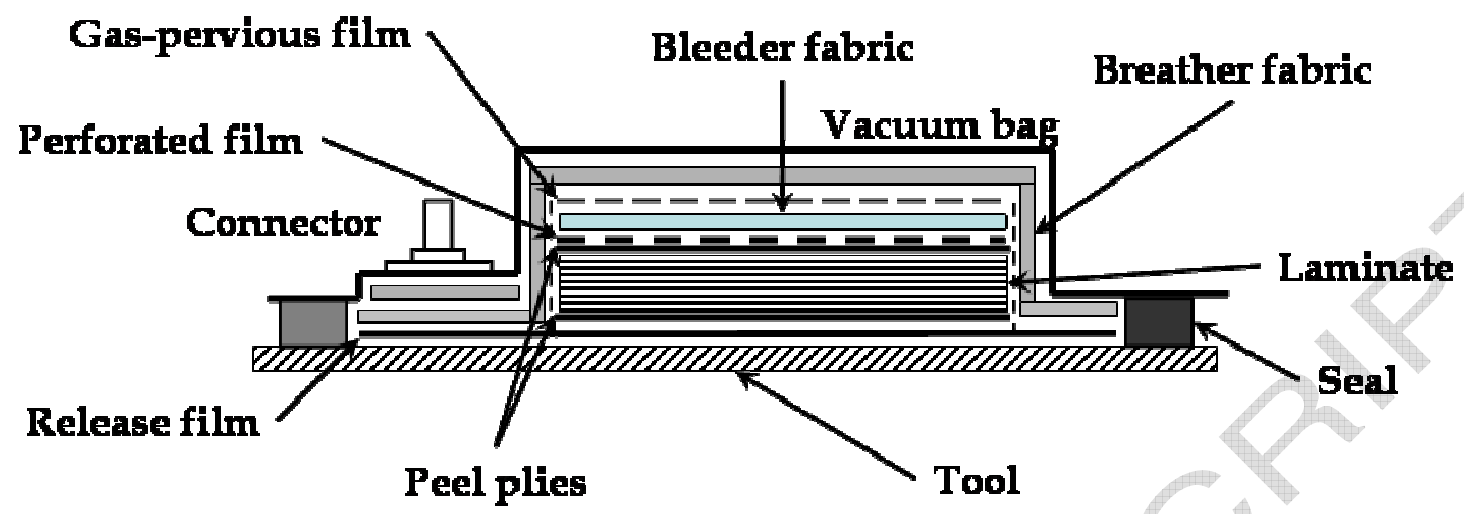


Figure 5: Symmetric quasi-isotropic lay-up

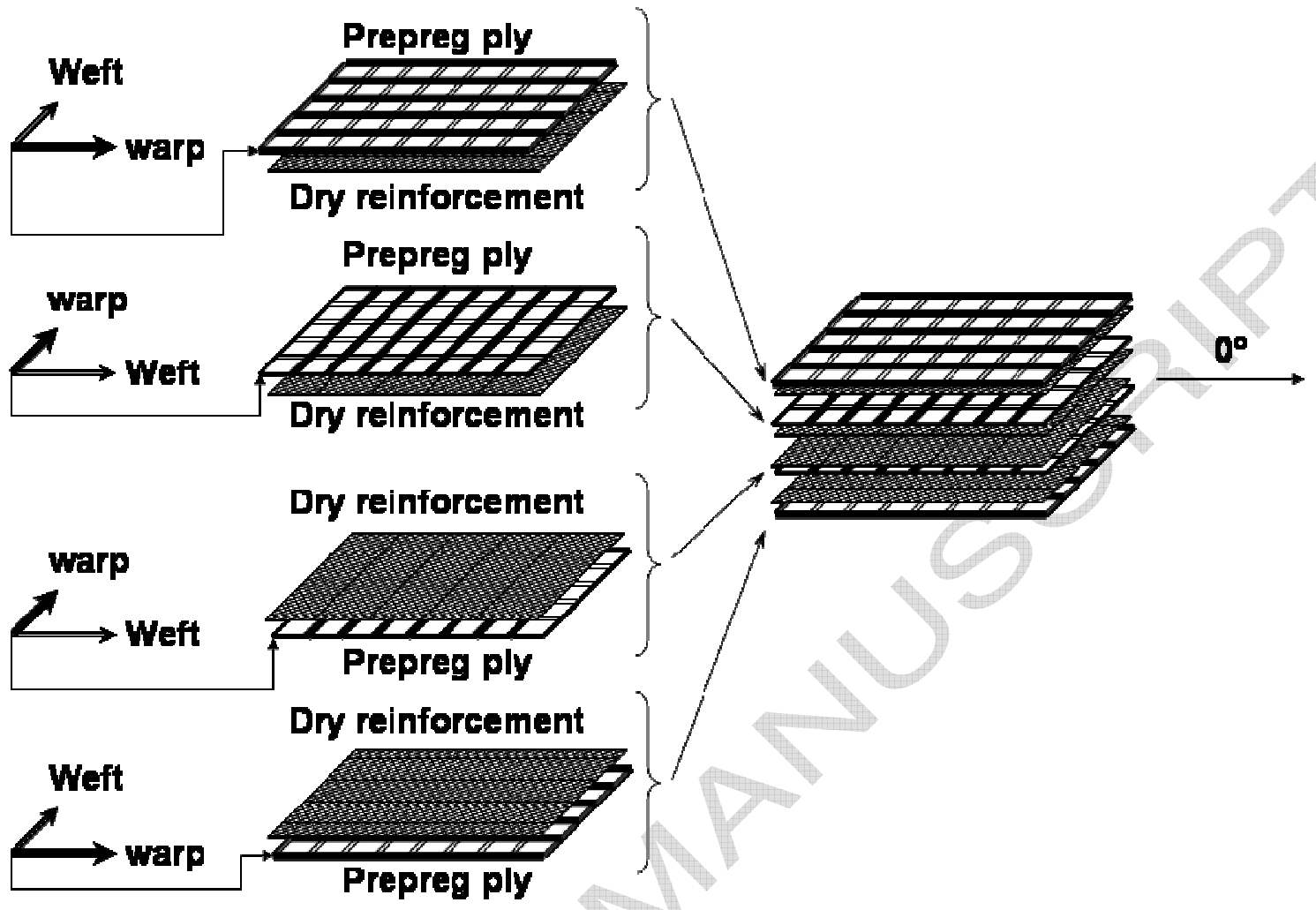


Figure 6:Ply structure

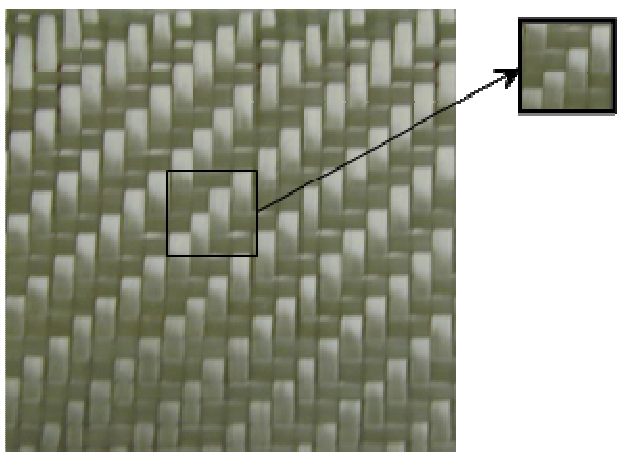

Repetitive cell

$\sim 20 \mathrm{~mm}$ side

7

Stitching

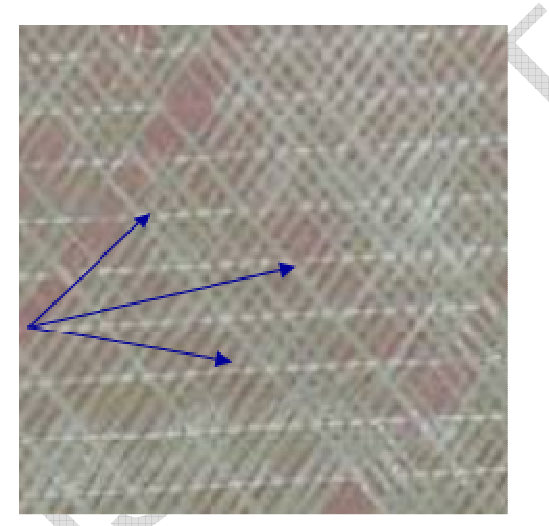


Figure 7: Thickness Ultrasonic cartography

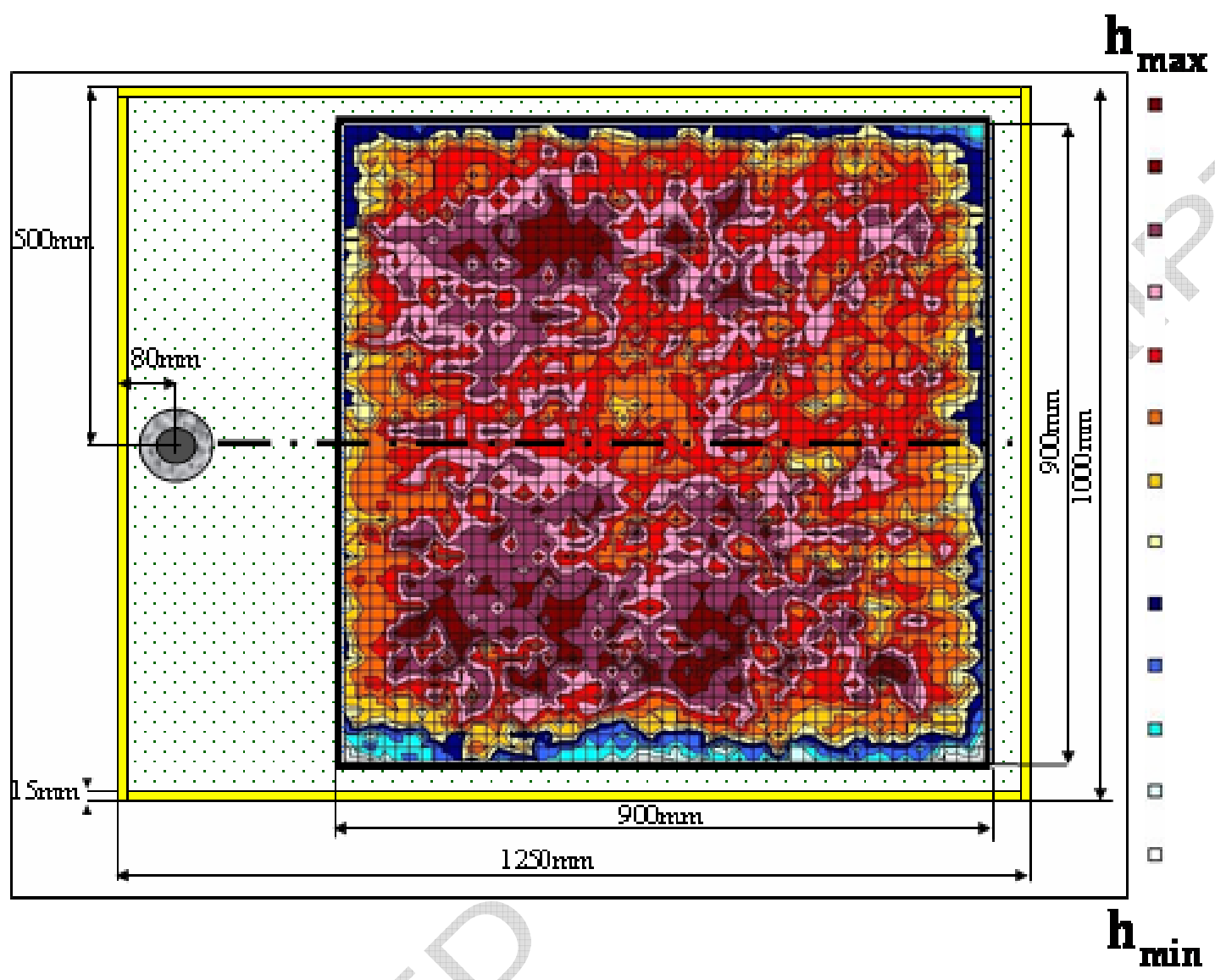


Figure 8: Infrared cartography

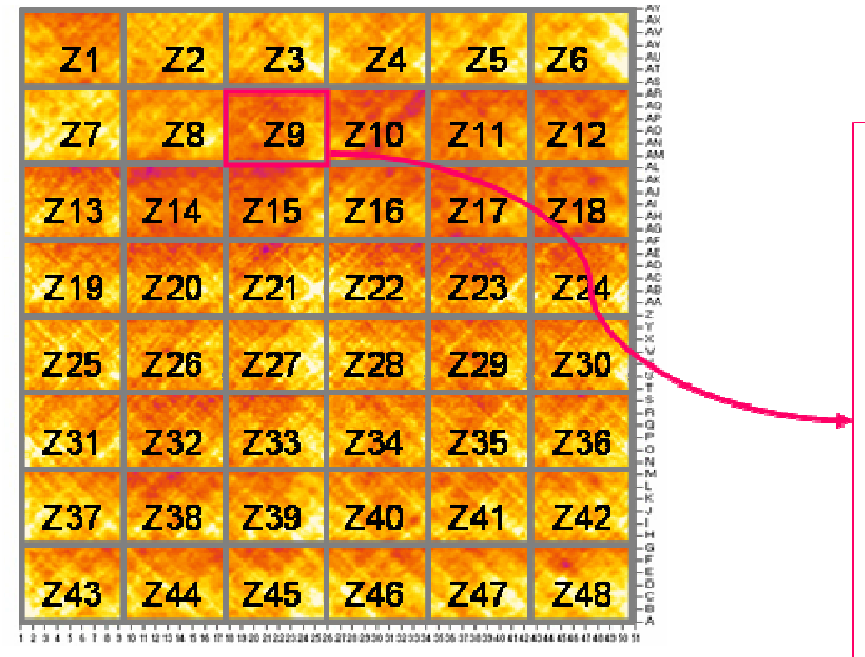

\begin{tabular}{|l|c|c|c|c|c|}
\hline$Z 1$ & $Z 2$ & $Z 3$ & $Z 4$ & $Z 5$ & $Z 6$ \\
\hline$Z 7$ & $Z 8$ & $Z 9$ & $Z 10$ & $Z 11$ & $Z 12$ \\
\hline$Z 13$ & $Z 14$ & $Z 15$ & $Z 16$ & $Z 17$ & $Z 18$ \\
\hline$Z 19$ & $Z 20$ & $Z 21$ & $Z 22$ & $Z 23$ & $Z 24$ \\
\hline$Z 25$ & $Z 26$ & $Z 27$ & $Z 28$ & $Z 29$ & $Z 30$ \\
\hline$Z 31$ & $Z 32$ & $Z 33$ & $Z 34$ & $Z 35$ & $Z 36$ \\
\hline$Z 37$ & $Z 38$ & $Z 39$ & $Z 40$ & $Z 41$ & $Z 42$ \\
\hline$Z 43$ & $Z 44$ & $Z 45$ & $Z 46$ & $Z 47$ & $Z 48$ \\
\hline
\end{tabular}

\section{Comparison IR I US}

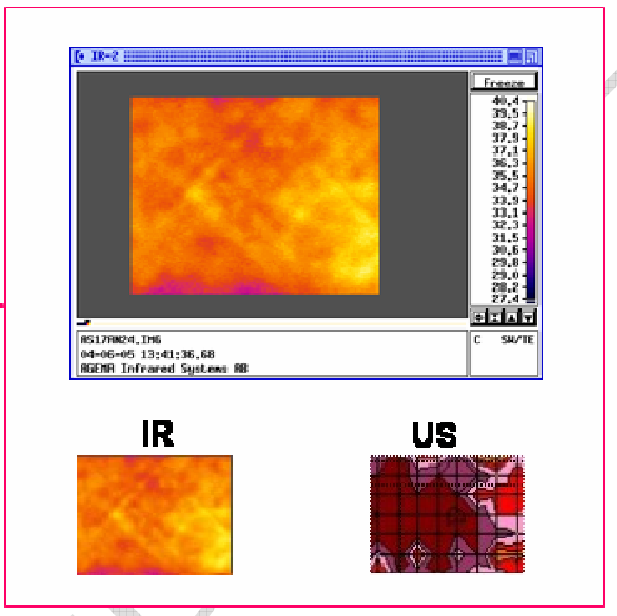

\section{Comparison IR I US}

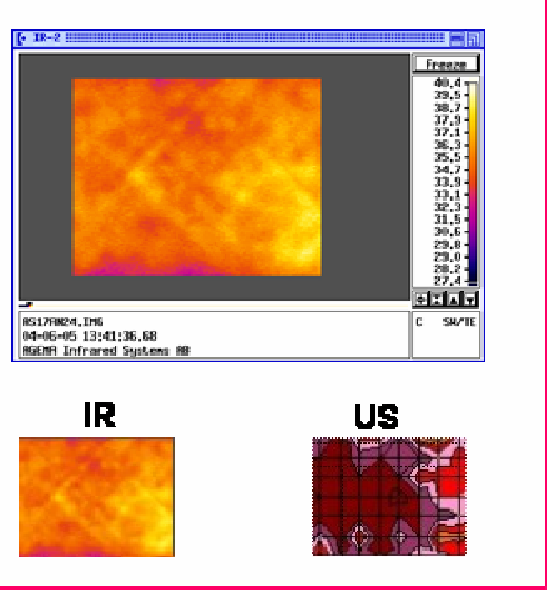




\section{ACCEPTED MANUSCRIPT}

Figure 9: $X$ radiography of test blocks ( 4 plies): resp. \pm 45 and $2 \times 2$ twill
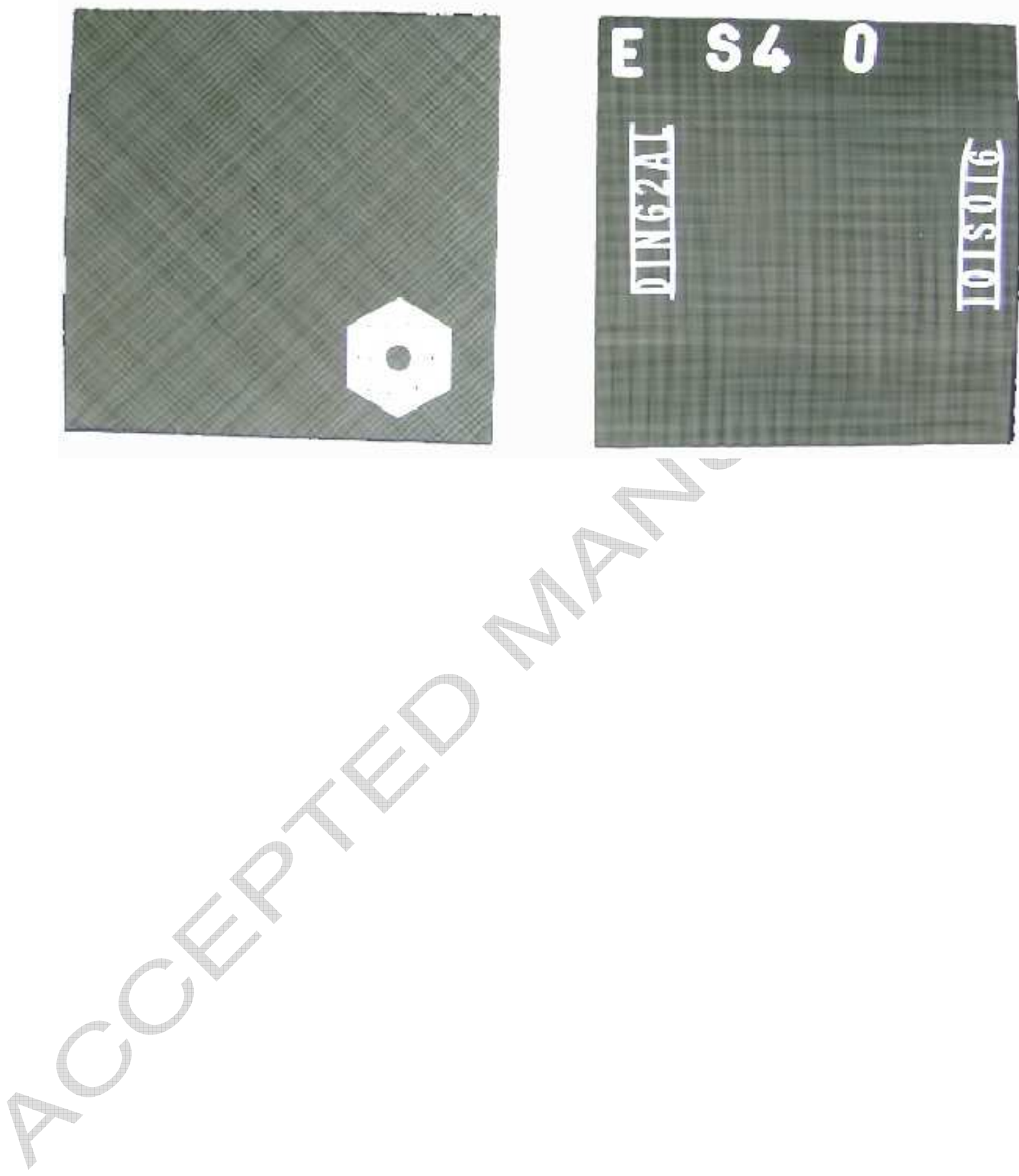
Figure 10 : Tensile specimens selected with regards to ultrasonic cartography

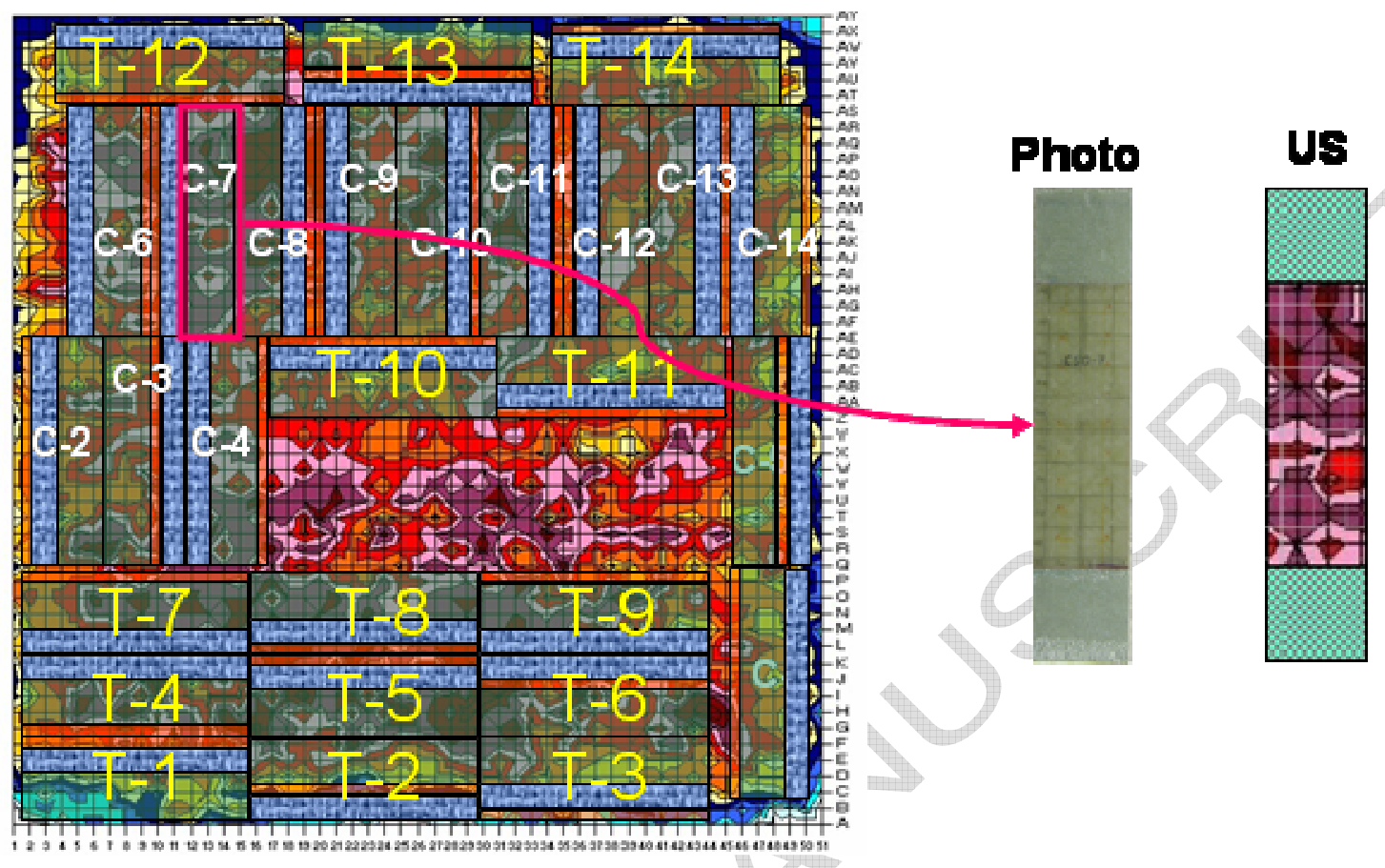


Figure 11 : Load-extension diagrams for widths: 10, 25 and $50 \mathrm{~mm}$
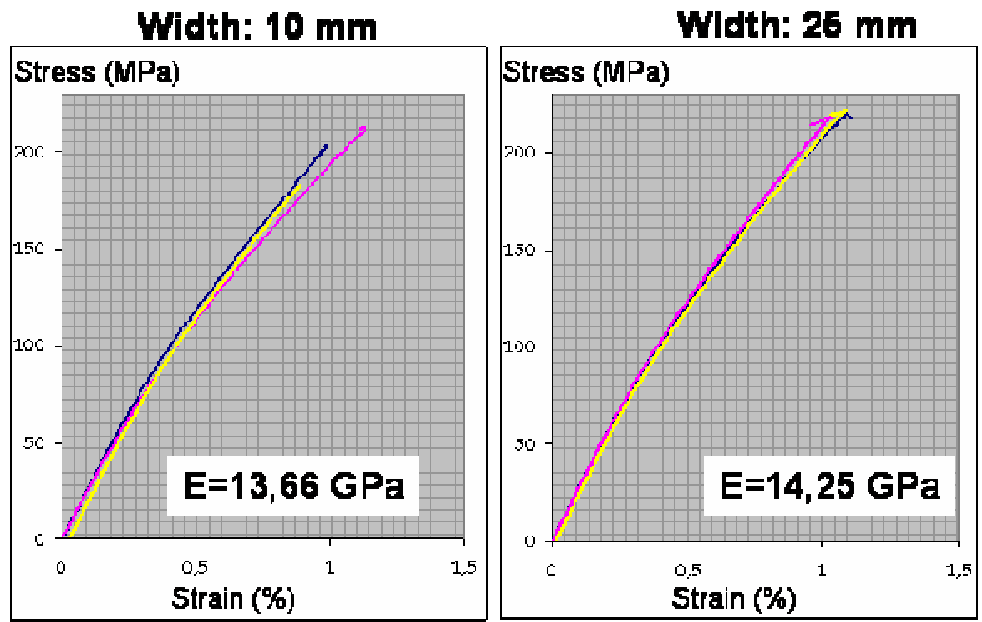

Width: $50 \mathrm{~mm}$

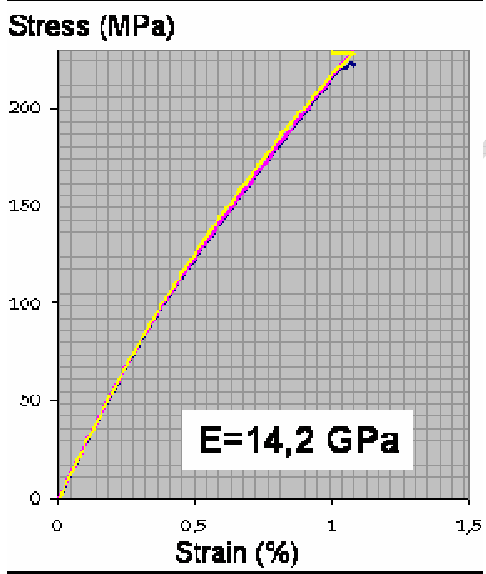


Figure 12 : Multi-instrumented specimens

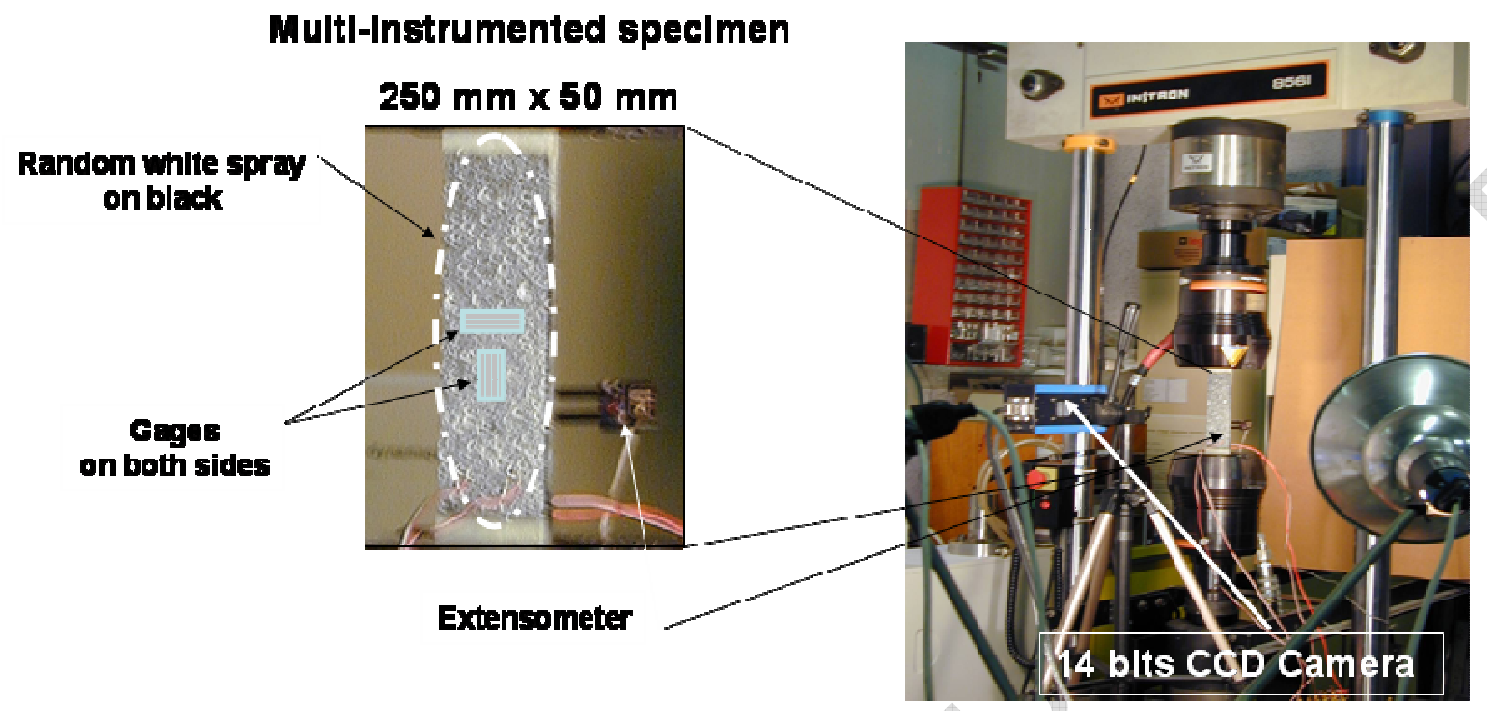


Figure 13 : Multi-instrumentation results, $10 \mathrm{~mm}$ gauges

\section{Transverse strah fields}
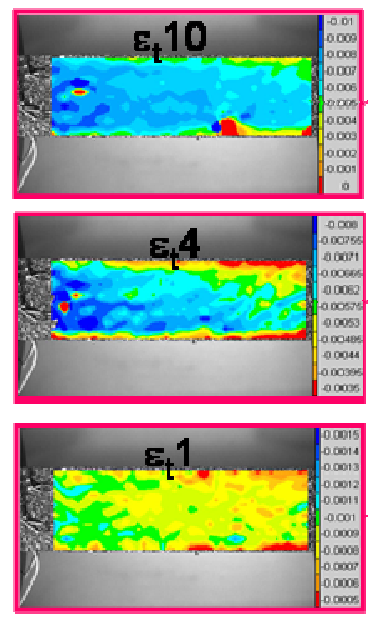

\section{Longltudinal straln flelds}

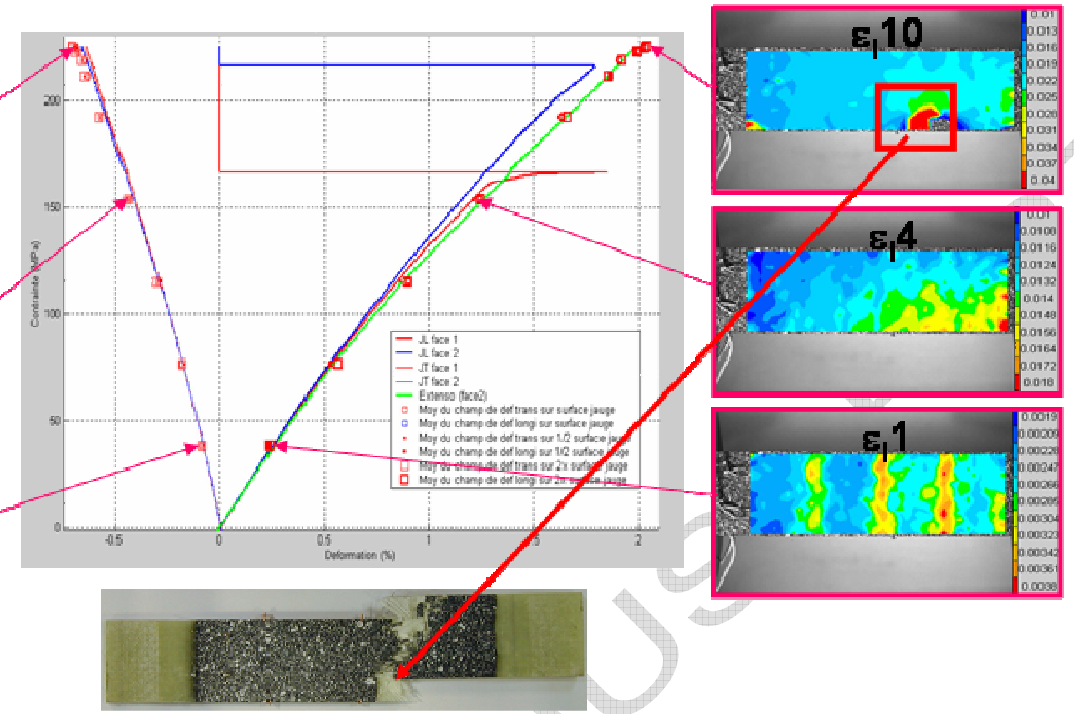




\section{ACCEPTED MANUSCRIPT}

Figure 14 : Multi-instrumentation results, 6 mm gauges

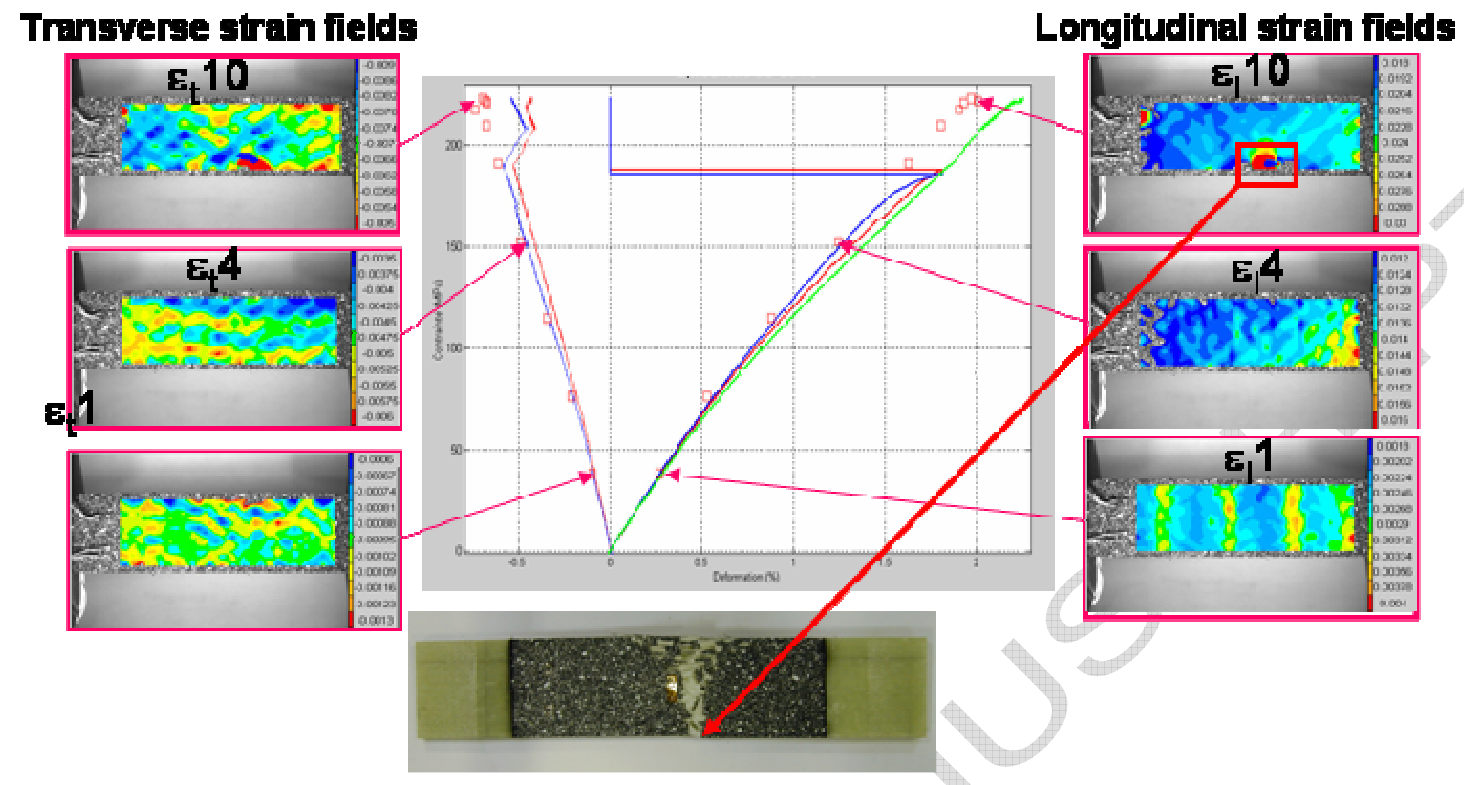

